\title{
THE IMPLEMENTATION OF SCIENCE, TECHNOLOGY, ENGINEERING AND MATHEMATICS (STEM) ACTIVITIES AND ITS EFFECT ON STUDENT'S ACADEMIC RESILIENCE
}

\author{
Titiyaka Jajuri*, Shahabuddin Hashim, Mohd Norawi Ali and \\ Syed Mohamad Syed Abdullah \\ School of Educational Studies, Universiti Sains Malaysia, 11800 USM Pulau Pinang, \\ Malaysia \\ *Corresponding author: titiyakajajuri@yahoo.com
}

Publication date: 24 December 2019

To cite this article: Titiyaka Jajuri, Shahabuddin Hashim, Mohd Norawi Ali, \& Syed Mohamad Syed Abdullah. (2019). The implementation of Science, Technology, Engineering and Mathematics (STEM) activities and its effect on student's academic resilience. Asia Pacific Journal of Educators and Education, 34, 153-166. https://doi. org/10.21315/apjee2019.34.8

To link to this article: https://doi.org/10.21315/apjee2019.34.8

\begin{abstract}
Surfing the Fourth Industrial Revolution is an elegant way to bridging human and machine intelligence through learning systems that support creativity and innovation among students. The students with science, technology, engineering and mathematics (STEM) skills can develop required advance systems by bringing together artificial intelligence and everything in the digital economy. Hence, by actively doing STEM activities, students can explore the extent of their creative and analytical thinking through multimedia as example using Google Classroom. By applying the Social Constructivism Theory as proposed by Vygotsky and Bronfenbrenner's Cultural-Ecological Transactional Theory in the education framework, this study aims to discover the implementation of STEM activities and its effect on students' academic resilience. The data is collected from a group of experts using the fuzzy Delphi technique for the usability of the module that implements STEM activities. It is found that academic resilience can widen the inner strength of the students from four aspects which are social support, social skills, planning priority behaviours and goal efficiencies. In conclusion, by conceptualising digital learning in implementing STEM activities can produce quality students who can compete globally and mastering technological developments.
\end{abstract}

Keywords: STEM activities, academic, resilience, fuzzy Delphi 


\section{INTRODUCTION}

As we enter the 4th Industrial Revolution, the conversation about the future of Science, Technology, Engineering and mathematics (STEM) education must centre around both what we teach and how we teach it. The 4th Industrial Revolution represents a non-linear break with previous economic orders. Beginning with earlier Industrial Revolutions based on advances in steampowered transportation and mechanical production (late 18th century), standardised electrically powered mass production (late 19th century), and the computer revolution (late 20th century), then continue by the 4th Industrial Revolution which is the integration of digital, physical, and biological systems (Schwab, 2017). Further, these technologically driven shifts have the potential to further drive economic inequality, and to concentrate wealth and power amongst a small set of companies and individuals as well as policymakers worldwide that focusing on increasing the number of diversity of STEM students. So how can we better apply a technological change lens to understand the future of STEM education as an industry?

Therefore, we should expand the scope of STEM education, to ensure that students learn to evaluate and respond to the social, economic and political consequences of their work. By actively doing STEM activities using the module, students can explore the extent of their creative and analytical thinking through multimedia as example using Google Classroom. In addition, all STEM activities encourage students to bring out their hidden artistic selves, and express themselves in ways, they had never been able do before. However, we need to start seeing computer screens not simply as information machines, but also as a new medium for creative design and expression. The more student learn about the abilities of technology, the more creative they become.

Furthermore, all the STEM activities that being integrated with arts disciplines provide the innovation, entrepreneurial attitude, emotional and social intelligence required for widen the inner strength of four aspects on student's academic resilience. It is similarly emphasising the importance of developing non-cognitive skills in students: skills like perseverance, conscientiousness, team working and interpersonal skills by using the four aspects that we focusing on academic resilience which are social skills, social support, goal efficiencies and planning priority behaviours. All these are needed to enhance academic resilience among STEM students.

This paper will cover all STEM activities that are in line with the needs of the industrial revolution and thus form a resilient student. Resilience is needed in 
society so that they can face the changing environment in mastering technological developments and have a high degree of competitiveness and thus able to compete globally to face the industrial revolution.

\section{LITERATURE REVIEW}

Resiliency is not only the ability to survive in difficulty, but also as a therapy. Thus, resilience is a multidimensional construct that can optimise one's function and is the basic concept for positive psychology (Seligman \& Csikszentmihalyi, 2000, p. 55). According to Reivich and Shatté (2002), resilience is the ability to provide productive feedback when facing obstacles or trauma. Hashim, Ahmad and Yusof (2014) stated that resiliency is a source of strength to face the challenges of life and ability to adapt the stresses either internally or externally. By doing STEM activities, their academic resilience will increase when they survive in any situation and faced with adversity or challenges experienced in learning has led to the key to success, excellence and satisfaction of learning. It is found that the crucial thing about this review is to revise whether the four aspects including social skills, social support, goal efficiencies and planning priority behaviours can drive the whole direction of STEM education to fulfil academic resilience contexts. Many of STEM students are found to be lacking in creativity, communications skills, analytical and critical thinking, and problem-solving skills (Teo \& Wong, 2000; Tan, 2000). So-called soft skills such as: judgement, empathy, persuasion, the ability to collaborate and communicate, and be flexible, adaptable and resilience are just a few of the skills that machines are unable to replicate (Letellier, 2018).

Fortunately, the seeds of this educational revolution are already sprouting. As example, Stanford University develop an entirely new curriculum that gives the next generation of technologists, engineers, scientist and mathematicians with its deep links to the tech industry with Program in Technology and Humanity. This is a good first step, but much more must be done (Baker, 2018). All these early initiatives can gain a deeper understanding of STEM students how technology affects humanity. Which STEM skills will be the most critical for humans to have in the future?

Since the STEM idea was first introduced in the United States in the early 90's, one of the ideal STEM goals was to train students to collaborate and communicate in carrying out learning activities (Bunyamin, 2016). By applying the Social Constructivism Theory as proposed by Vygotsky (1978), student practicing communication skills (social skills) will get better at asking for help and expressing what they need, and over time they will develop the skills and confidence to tell 
the others more clearly what they have learned in class or while doing their STEM activities. Indeed, Vygotsky posited that knowledge can be constructed through social interactions (Fung, 2017). Healthy communication is vital to thriving workplace communities, and it's essential for effective collaborative classrooms as well. In STEM education, empathetic communication is a fundamental ingredient for success. Whether teacher or student must be able to take highly technical knowledge and describe it in a clear and simple way for others. If students learn to express ideas in a persuasive way and respond gracefully to reactions to their opinions, they'll be able to promote innovation and social change through fields that they learned. Teacher may not be able to see the outcomes of bolstering students' communication right away, but the transfer to real-world situations will one day be undeniable.

To study a student's academic resilience then, we must look not only at the student and their immediate environment, but also at the interaction of the larger environment as well. Social support is another important factor that have been implemented in a variety of STEM education to help promote greater engagement of student in STEM education (Rosenthal, London, Levy, Lobel, \& HerreraAlcazar, 2011). As Bronfenbrenner (1979) points out about Cultural-Ecological Transactional Theory that looks at a student's development within the context of the system of relationships that form his or her environment. Community benefits because they are an important part of curriculum support as they bring in their expertise to drive student innovation and curiosity about real-world situations regarding STEM education. Findings that tested participants in four adolescent school settings by University of Alabama in year 2012, suggest that students who perceive greater social support for math and science from parents, teachers, and friends have more positive attitudes toward math and science and a higher sense of their own competence in these subjects (Rice, Barth, Guadagno, Smith, \& McCallum, 2013).

Another perspective that influence student's academic resilience is all about goal efficiencies and how it is managed. Each student are born with their own leadership powers and as they grow up some of them keep their talent active while others unconsciously keep it dormant (Mestre, 2008). The goals efficiencies in STEM education plan will support building and maintaining the STEM pipeline, reducing the number of STEM professionals who choose to leave this field and keeping competitive with industry and other countries also seeking STEM talent. This proven by neuroscience research and hence, all teachers and parents need to realize this potential and try to make them become great and revolutionary creativity in many ways (Akyeampong, 2018). In this study, google classroom is used as technological tools that help enhance student's leadership when students are 
responsible in determining team goals in each STEM activity as well as reporting them through their respective websites and sharing the experiences they have shared with other friends that can be of great help to teachers in this endeavour. Well, in this modern era of technology, the solution becomes very simple, to utilise technology to keep student's character intact and flowing.

To deliver the STEM education aspirations as outlined in the related policy, Ministry of Education (MOE) together with Ministry of Science, Technology and Innovation (MOSTI) and Ministry of Higher Education (MOHE) are currently developing a National STEM action plan which involves all government agencies in Malaysia and in collaboration with private sectors (Mohd Shahali, Ismail, \& Halim, 2017). Thus, a strong planning in STEM education is becoming increasingly recognized as a key driver of opportunity, and data show the need for STEM knowledge and skills will grow and continue into the future (Ministry of Education [MOE], 2013). Those graduates who have practical and relevant this skill precepts embedded into their educational experiences will be in high demand in all job sectors. It is estimated that the New Economic Model (NEM) aims to create 1.3 million jobs in STEM discipline in various sectors by 2020 for our country, enabling infrastructure and supporting the development of industrial clusters (MOE, 2013). Specifically from all literature review above, an analytical look at the concept of academic resilience in STEM education was still lack so this study can prove that these four elements; social skills, social support, goal efficiencies and planning priority behaviours are able to enhance students' academic resilience which is very important in the industrial revolution.

\section{METHODOLOGY}

A module is developed to discover the implementation of STEM activities and its effect on students' academic resilience. A module is a set of studies or programs which have been systematically planned and organised to achieve a number of objectives. The purposes of a module are to identify clearer objectives of the teachings and to arrange activities more systematically (Russell, 1973; Mohd Noah \& Ahmad, 2005). Module design is not only for inside classroom learning process, but also for activities outside the classroom (McArdle, 2007). A module can be developed by using two approaches. First, the module development can be based on the study of certain theories, models, literature or the consensus of the experts. Second, the module development can be adapted from the other existing modules or models to suit the needs of the study (Milano \& Ullius, 1998; Richey \& Klein, 2007). 
Development research involves along this development of module consist of several phases and steps. Development of the module engaged with certain models of module development that suit the module objective. An appropriate model of this study is the adaption of ADDIE Module Development Model. The ADDIE model is chosen because the model is the most frequently used for teaching module design, furthermore its sequence of systematic teaching design processes and is the basis of other design models (Ali, Ibrahim, Abdullah, Surif, Abdul Talib, \& Saim, 2015).

Based on the model, the module development in this study can be segregated into five phases:

First Phase: Analyse System Requirements (Literature analysis and needs analysis)

Second Phase: Define Education Training (Design of the module)

Third Phase: Define Course Objectives and Tests (Pilot study)

Fourth Phase: Plan, Develop, and Validate Instruction (Development of the module)

Fifth Phase: Conduct and Evaluation (Evaluation of the module)

This research used content analysis and quantitative method. These methods were used in order to identify whether the STEM activities that contains in the module is necessary in fostering student's academic resilience. Content analysis method was implemented to explore the relevant theory and literature regarding the significance to increase student's resilience while the quantitative method involved distributing to determine the views and expert consensus for the usability of the module.

The Fuzzy Delphi Method (FDM) was conducted to get verification from the experts. Similar to Delphi technique, FDM is a procedure to determine the views and expert consensus on something (Anderson, 1975; Brown, 1968; Dalkey, 1967). However, FDM application was applied to overcome the weaknesses in the traditional Delphi technique such as the loss of data due to an iterative process which usually takes a long time (Mohd Jamil, Siraj, Hussin, Mat Noh, \& Sapar, 2014). Moreover, FDM is an approach which can avoid appointing a person who is not an expert as it needs lesser respondents compared to Delphi technique which requires large number of respondents (Siraj, 2008). 
Module POYO Development Questionnaires are given to the experts involved and FDM was conducted to get verification from the experts. This study involved 11 experts which consist of Guidance and Counselling lecturers, Physics experts, language experts, Module developer, comprising five males and six female experts currently serving in secondary schools and university. Criteria for sample selection are based on the skills and knowledge that they have in the own expertise, specifically for secondary school students. The criteria to become an expert in this study at least five year experiences regarding to their field. Jones and Twiss (1978) stated that the number of experts for the application of Fuzzy Delphi Technique is between 10 to 50 experts. This is also confirmed by Adler and Ziglio (1996) who claimed that if the agreement and consistency of experts is high, the number of 10 to 15 experts is sufficient.

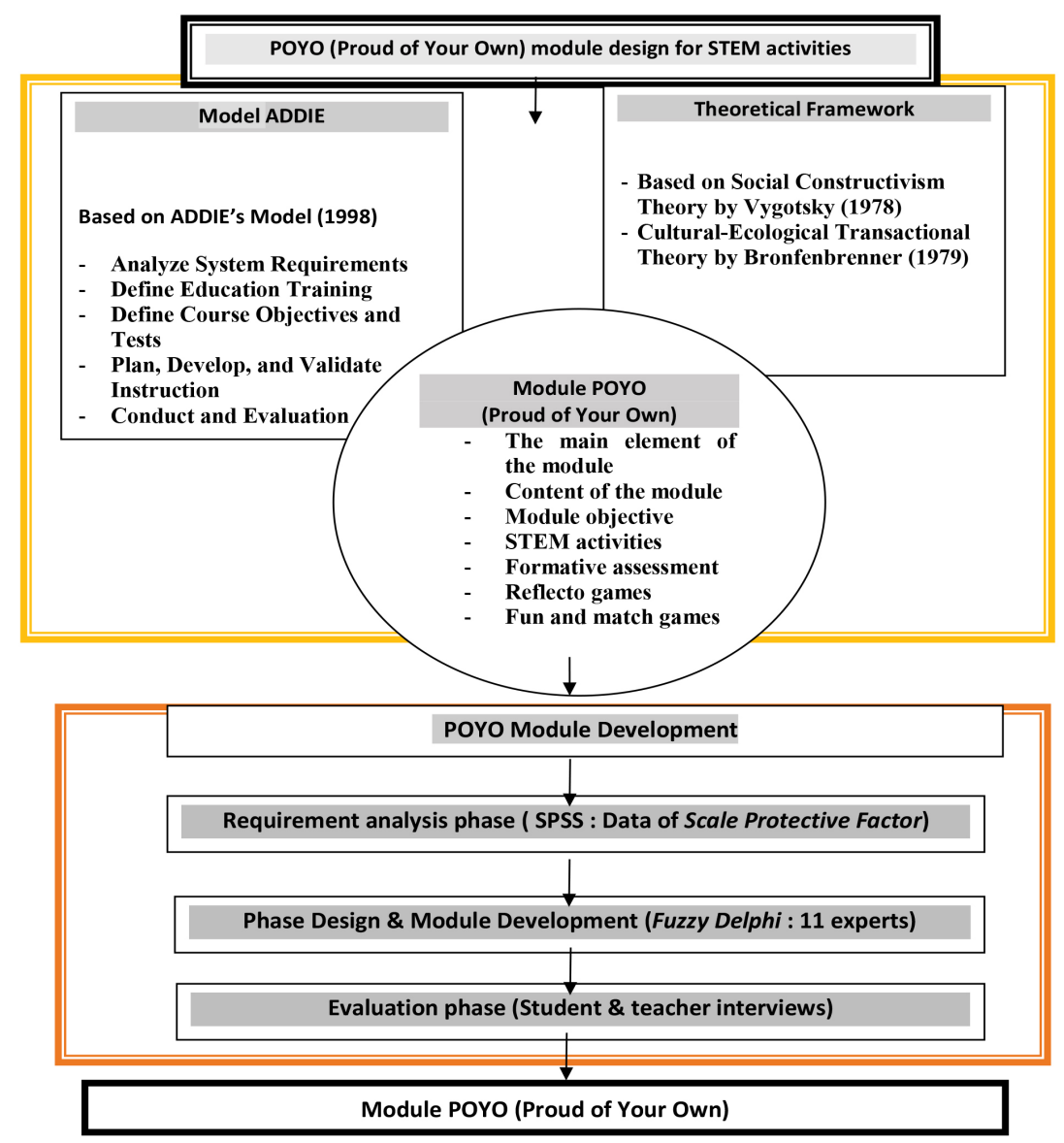

Figure 1. Conceptual framework of study (Source modified from Richey \& Klein, 2007) 


\section{RESULTS}

Tables 2 and 3 shows the threshold $(\mathrm{d} m, n)$ for each item based on the expertise and the overall percentage threshold for the consensus group of experts on the usability of the module that implements STEM activities. Overall, all items agreed upon by experts based on a percentage of the experts agreed. To ensure the usability of the module for STEM's education and academic resilience needs, the data of the findings must comply with the requirements for the established Fuzzy Delphi (FDM) approach which are:

\section{Triangular Fuzzy Numbers}

1. Threshold value $(\mathrm{d}) \leq 0.2$

Condition 1 involves threshold value (d). To measure the expert group agreement, the resulting threshold (d) value must be smaller or equal to 0.2 . In the context of this study, three decimal places are used. So each item containing threshold value (d) that does not reach value 0.3 and above will be translated as ACCEPTED based on expert agreement. Determining the threshold value (d) is based on the following formula:

$$
\mathrm{d}(\tilde{m}, \tilde{n})=\sqrt{\frac{1}{3}\left[\left(m_{1}-n_{1}\right)^{2}+\left(m_{2}-n_{2}\right)^{2}+\left(m_{3}-n_{3}\right)^{2}\right]}
$$

2. Percentage consensus by experts $\geq 75 \%$

Condition 2 involves the percentage of expert group deals. This condition is based on a traditional Delphi method approach where this percentage value is determined based on the number of items containing threshold value (d) which does not reach value 0.3 and above. This means that each item with a threshold value (d) of equal or less than 0.2 will be ACCEPTED and converted to a percentage value based on the traditional Delphi method.

In all, Module POYO Development Questionnaires that consist of 12 questions were successfully returned and validated by all experts. The group consensus was estimated. The distance between two fuzzy numbers was calculated by measuring the deviation between the average fuzzy evaluation data and the expert's evaluation data. The value of 0.135 is less than the threshold value of 0.2 set by this research and is thus acceptable for the group consensus. To evaluate the group consensus, criterion that is used was based on the condition that the group agreement is greater than $75 \%$. The average of criteria weights is $97 \%$. 

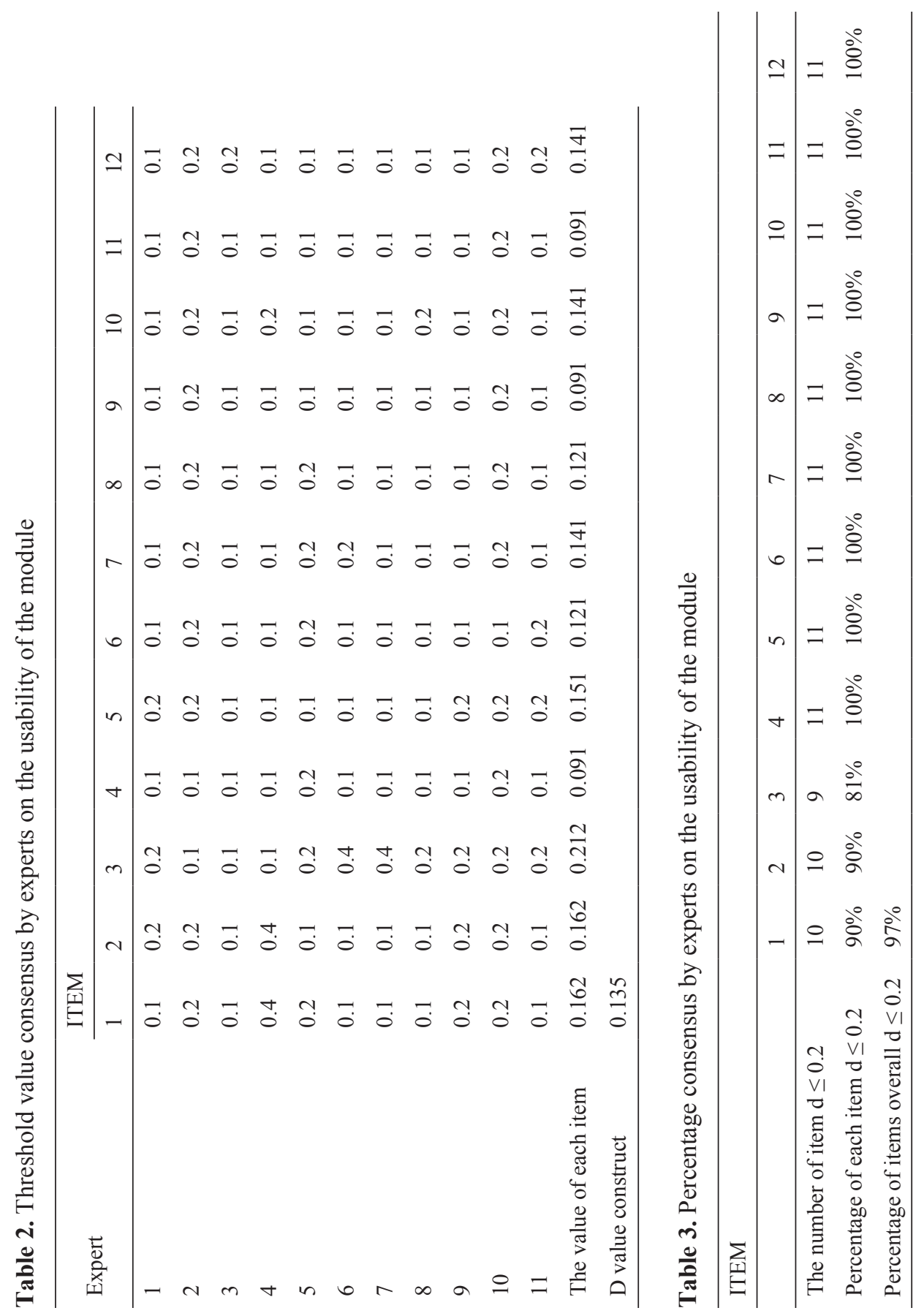


\section{DISCUSSION}

As a result of the defuzzification score for each domain item to identify whether the STEM activities that contains in the module is necessary in fostering student's academic resilience appears to be on the value agreed upon by all of them. It is hereby found all of the items can be used in the process in designing guidelines on the STEM activities that can widen the inner strength of the students from four aspects which are social skills, social support, goal efficiencies and planning priority behaviours and absolutely will increase student's academic resilience. In the context of learning through this module, students will be guided to actively participate in the STEM activities and learning environment. According to the researcher, when teachers present the STEM activities that integrated with the tools of technology will drive students to collaborative activities or projects. This is because, according to Harun and Tasir (2003), the Theory of Constructivism provides guidance and principles that should be considered when developing a technology based learning environment.

According to Baker (2018), there are several variables that can influence resilience among students for example social ability, problem solving skills, independence or self-reliance and have a distinct and clear goal. Furthermore, the aspects that are emphasised in social skills are communication skills through STEM activities will cause effective learning is an interactive process that gives students the opportunity to interact, mutually support, carry out responsibilities and build self-confidence in creating universal social development at school (Mohd Dazali \& Awang, 2014). In Nurul Salmi and Mohd Isa (2014) study, we found that there was significant relationship between communication skills and academic achievement.

STEM students with low resilient levels usually lack social support and are often subject to emotional changes such as feelings of low self-esteem, quietness, irritability and low motivation. Poor social support can also complicate the situation and cause problems (Tan \& Sutan, 2013). Good social support quality relationships will have positive implications for academic achievement (Mohd Salleh, 2003) as a result of self-esteem received from various parties such as parents, teachers and friends. Excellent academic achievement is influenced by parental support for students who are able to educate and shape a good child's personality, thus reducing disciplinary problems in school.

Besides that, the goal is important in STEM education because it is something that a student needs to accomplish by implementing certain actions and is very important to help motivate them in increasing their chances of success. Each STEM students has a high goal, dreams and ambitions to gain excellence in their 
academics (Kamaruddin \& Mohamad Rawan, 2010). Excellent students minimise the use of time through initial planning and effective action in achieving the desired goals in achieving learning excellence.

Final aspect is planning priority behaviours which affect by various factors that influence the behaviour of individual STEM students as an example of psychodynamic aspects in which the theory involving dynamically determined through the intrapsychic or internal approaches themselves. In terms of biophysical aspects, the behaviour is organically derived which is dependent on the individual physical and determined by external factors. Without effective planning, optimum results will not be achieved in producing a balanced, physically, emotionally and intellectually student. In previous studies, students still need the help of teachers in designing learning strategies in realising the goals they want to achieve.

\section{CONCLUSION}

For future studies, all information collected or respondent by students can be used to improve planning on STEM education that can contribute a high impact on the education system in line with the needs of the industrial revolution. STEM activities require a much more blended learning experience, with skills such as creative ingenuity and placing emphasis on design, entrepreneurship and ethics being required alongside technical STEM staples. Furthermore, all the STEM activities that being integrated with arts disciplines provide the innovation, entrepreneurial attitude, and emotional and social intelligence required for widen the inner strength of four aspects on student's academic resilience. It is similarly emphasising the importance of developing non-cognitive skills in students: skills like perseverance, conscientiousness, team working and interpersonal skills by using the four aspects that we focus on academic resilience which are social skills, social support, goal efficiencies and planning priority behaviours. The results indicate that referring to expert assessment, this module is in compliance with the estimated theory and also best suited for developing STEM students' academic resilience to achieve maximum potential for inner strength of the students from four aspects which are social skills, social support, goal efficiencies and planning priority behaviours. In conclusion, by conceptualising digital learning in implementing STEM activities can produce quality students who can compete globally and mastering technological developments. 


\section{REFERENCES}

Adler, M., \& Ziglio, E. (1996). Gazing into the Oracle: The Delphi Method and its application to social policy and public health. London: Jessica Kingsley.

Akyeampong, A. S. (2018). Promoting creativity and critical thinking through digital storytelling: Perceptions of undergraduate students. In B. Hokanson, G. Clinton, \& K. Kaminski (Eds.), Educational technology and narrative (pp. 271-282). Cham, Switzerland: Springer. https://doi.org/10.1007/978-3-319-69914-1_22

Ali, M., Ibrahim, N. H., Abdullah, A. H., Surif, J., Abdul Talib, C., \& Saim, N. (2015). Web Pro-Mc Physics as a support tool for improving physics problem solving skills. Paper presented at Game Physics and Mechanics International Conference (GAMEPEC), Langkawi, Malaysia. https://doi.org/10.1109/ GAMEPEC.2015.7331851

Anderson, F. T. T. (1975). A modified Delphi study of the political feasibility of critical issues affecting educational reform in Maryland. Unpublished doctoral dissertation, Virginia Polytechnic Institute and State University.

Baker, M. (2018). Hacking the STEM syllabus. Retrieved from https://www.projectsyndicate.org/commentary/ethical-technology-education-for-programmers-bymitchell-baker-2018-12

Bronfenbrenner, U. (1979). The ecology of human development: Experiments by nature and design. Cambridge, MA: The Harvard University Press.

Brown, B. B. (1968). Delphi process: A methodology used for the elicitation of opinions of experts. Santa Monica, CA: RAND.

Bunyamin, M. A. H. (2016). STEM education in Malaysia: Reviewing the current physics curriculum. Paper presented at The International Conference of Association for Science Teacher Education, Reno, Nevada.

Dalkey, N. C. (1967). Delphi. Santa Monica, CA: RAND.

Fung, C. Y. (2017). The use of Integrated Journal Discussion Board (IJDB) to improve student's motivational beliefs and self-regulated learning strategies in higher education. Unpublished doctoral dissertation, Universiti Sains Malaysia, Pulau Pinang, Malaysia.

Harun, J., \& Tasir, Z. (2003). Pengenalan kepada multimedia. Selangor, Malaysia: Venton Publishing (M) Sbn. Bhd.

Hashim, S., Ahmad, N. S., \& Yusof, H. (2014). Modul memperkasa sahsiah waja diri pelajar abad ke-21. Selangor, Malaysia: PTS Akademia.

Jones, H., \& Twiss, B. C. (1978). Forecasting technology for planning decisions. Macmillan, London: National Library of Australia. https://doi.org/10.1007/9781-349-03134-4

Kamaruddin, M. I., \& Mohamad Rawan, N. (2010). Kaitan faktor penyumbang dengan kecemerlangan akademik pelajar asrama harian. Retrieved from http://eprints. utm.my/id/eprint/10262/2/Nuremelia_binti_Mohamad_Rawan.pdf

Letellier, R. (2018). Making STEM education relevant in the fourth industrial revolution. Retrieved from https://rmresults.com/blog/making-stem-education-relevant-inthe-fourth-industrial-revolution 
McArdle, G. E. (2007). Training, design and delivery: A guide for every trainer, training manager and occasional trainer. Alexandria, VA: ASTD Press.

Mestre, J. P. (2008). Learning goals in undergraduate STEM education and evidence for achieving them. Retrieved from https://sites.nationalacademies.org/cs/groups/ dbassesite/documents/webpage

Milano, M., \& Ullius, D. (1998). Designing powerful training: The sequental-iterative model. San Francisco, CA: Jossey-Bass.

Ministry of Education Malaysia (MOE). (2013). Malaysia Education Blueprint 2013-2025. Putrajaya: MOE and Ministry of Science, Technology and Innovation (MOSTI). Retrieved from https://www.moe.gov.my/index.php/menumedia/media-cetak/ penerbitan/dasar/1207-malaysia-education-blueprint-2013-2025/file

Mohd Jamil, M. R., Siraj, S., Hussin, Z., Mat Noh, N. R., \& Sapar, A. A. (2014). Pengenalan asas kaedah Fuzzy Delphi dalam penyelidikan reka bentuk pembangunan. Selangor, Malaysia: Minda Intelek Agency.

Mohd Noah, S., \& Ahmad, J. (2005). Pembinaan modul: Bagaimana membina modul latihan dan modul akademik. Serdang: Universiti Putra Malaysia.

Mohd Salleh, R. (2003). Hubungan antara penghargaan kendiri dengan sokongan sosial dan pencapaian akademik, pelajar tahun enam, Sekolah Kebangsaan Kesom, Kuala Terengganu. Retrieved from http://www.fp.utm.my/ePusatSumber/Tb_psm_list

Mohd Shahali, E. H, Ismail, I., \& Halim, L. (2017). STEM education in Malaysia: Policy, trajectories and initiatives. Science and Technology Trends Policy Trajectories and Initiatives in STEM Education, 8(2), 2234-1889.

Nurul Salmi Mohd Dazali, \& Mohd Isa Awang. (2014). Tahap kemahiran komunikasi dalam kalangan pelajar Sarjana Muda Pendidikan IPTA di Utara Semenanjung Malaysia. Jurnal Pendidikan Bahasa Melayu; Malay Language Education (MyLEJ), 4(2), 44-56.

Reivich, K., \& Shatté, A. (2002). The resilience factor. New York: Broadway Books.

Rice, L., Barth, J. M., Guadagno, R. E. Smith, G. P. A., \& McCallum, D. M. (2013). The role of social support in students' perceived abilities and attitudes toward math and science. Journal of Youth Adolescence, 42(7), 1028-1040. https://doi. org/10.1007/s10964-012-9801-8

Richey, R. C., \& Klein, J. D. (2007). Design and development research: Methods, strategies and issues. London: Erlbaum.

Rosenthal, L., London, B., Levy, S. R., Lobel, M., \& Herrera-Alcazar, A. (2011). The relation between the Protestant work ethic and undergraduate women's perceived identity compatibility in STEM majors. Analyses of Social Issues and Public Policy, 11(1), 241-262. https://doi.org/10.1111/j.1530-2415.2011.01264.x

Russell, J. D. (1973). Modular instruction: A guide to the design, selection, utilization and evaluation of modular materials. Minneapolis, MN: Burgess Publishing Company.

Schwab, K. (2017). The fourth industrial revolution: What it means and how to respond. Retrieved from https://www.weforum.org/agenda/2016/01/the-fourth-industrialrevolution

Seligman, M. E. P., \& Csikszentmihalyi, C. (2000). Positive psychology: An introduction. American Psychologist, 55(1), 5-14. https://doi.org/10.1037/0003-066X.55.1.5 
Siraj, S. (2008). Future curriculum. Kuala Lumpur, Malaysia: University of Malaya.

Tan, O. S. (2000). Intelligence enhancement and cognitive coaching in Problem-based Learning. In C. M. Wang, K. P. Mohanan, D. Pan, \& Y. S. Chee (Eds.), TLHE Symposium Proceedings. Singapore: National University of Singapore.

Tan, S. C., \& Sutan, R. (2013). Faktor-faktor sokongan sosial yang mempengaruhi penghargaan kendiri remaja Sekolah Menengah Daerah Melaka Tengah. e-BANGI: Jurnal Sains Sosial dan Kemanusiaan, 8(1), 20-29.

Teo, R., \& Wong, A. (2000). Does problem based learning create a better student: A reflection? Paper presented at the 2nd Asia Pacific Conference on Problem, Education Across Disciplines, 4-7 December, Singapore.

Vygotsky, L. (1978). Interaction between learning and development: Readings on the development of children. New York: Scientific American Books. 